\title{
THE FIRST AMENDMENT AND COGNITION: A RESPONSE
}

\author{
CASS R. SUNSTEIN*
}

I am grateful to the editors of the Journal for imviting me to reply to Professor Chevigny's thoughtful responsel to my essay in these pages. ${ }^{2}$ I find myself in agreement with much of Professor Chevigny's argnment. A purely Cartesian account of human thought would indeed be hard to sustain. Human beings do not approach problems hinearly or through propositions alone. Drives, selective empathy and identification, heuristics of various sorts, prior experience and beliefs, desires, recognizable patterns, and various verbal and nonverbal cues also play a crucial role. Moreover, much speech with noncognitive components is entitled to the highest degree of constitutional protection. Political speech, for example, frequently appeals to the heart as well as to the head. The fact that an appeal is emotionally loaded is hardly a good reason to allow the government to control it.

Notwithstanding these points, it would, I think, be a mistake to abandon the view that some narrowly defined categories of speechthreats, involuntary hypnosis, and most notably, for present purposes, pornography -merit less than the usual protection, and precisely because of the way these kinds of speech communicate their "message." My claim comes in two simple parts. (1) Some narrowly drawn categories of speech may be regulated on the basis of a lesser showing of harm-a proposition that is in fact a staple of current first amendment doctrine. (2) To decide whether speech falls within those categories, it is relevant whether the material in question appeals to cognitive or noncognitive capacities. I arrive at this conclusion through two different routes.

First: I think Professor Chevigny overstates his case. The distinction between cognitive and noncognitive speech is not "dangerously incoherent." 3 Indeed, Professor Chevigny's own terms suggest that he believes that the distinction is intelligible, at least in the important sense that it is possible to identify polar cases. For example, he distinguishes

* Karl N. Llewellyn Professor of Jurisprudence, Law School and Department of Political Science, University of Chicago.

1. Chevigny, Pornography and Cognition: A Reply to Cass Sunstein, 1989 DukE L.J. 420.

2. Sunstein, Pornography and the First Amendment, 1986 DUKE L.J. 589.

3. Chevigny, supra note 1 , at 422 . 
between "the most professorial" and the "most intuitive" "; between "propagandistic persuasion" and other kinds of thought; between "prejudgments . . . in patterns" and "logic";6 between "arous[al]" and "abstract" argument.7 To be sure, Professor Chevigny often invokes these distinctions to suggest that they are less crisp and clear than we normally recognize-a claim I accept-but it is hard to read his essay without getting the sense that it would be difficult indeed to proceed without distinctions of this general sort. For this reason, Professor Cheviguy's colleague is on to something true and important when she says, $\mathrm{i}$ response to his essential argument, that what makes pornography different is that people "get off on it." 8 But more on this below.

More fundamentally, the proposition that "our judgments [appear] 'detached' or contemplative, but they are as much rooted in our prejudgments as are snap decisions," 9 is not merely a counsel of despair. This proposition-to which I very much doubt Professor Chevigny entirely subscribes-is also antithetical to the basic logic of a system of free expression, which places a high premium on the process of discussion and deliberation among people with different views. If judgments, contemplative judgments, snap judgments, and prejudgments are essentially all one, it will not be easy to specify the sorts of values our system of free speech should serve. Indeed, common practices of deliberation, commumication, change im perspective, and learning will be hard to sustain.

In any case, Professor Chevigny's effort to collapse the distinction between the cogmitive and noncogmitive is emphatically not the lesson of the various writings on which he relies. Those writings convey no single message, but make a variety of quite distinct clains, some of them fundamentally at odds with Professor Chevigny's position. Either separately or together, they do not support Professor Chevigny's effort to collapse the distinction between reasoned judgments and bare intuition. ${ }^{10}$
4. Id. at 424 .
5. Id. at 426 .
6. Id. at 428 .
7. Id. at 430 .
8. Id. at 428 .
9. Id. at 427; see also id. at 426 ("We cannot escape from our stereotypes through 'rationality" or 'detachment' because they are the principal tools we have."). The same position-a form of conventionalism-can be found in S. Fish, Doing What Comes Naturally (1989); it is criticized in Sunstein, Interpreting Statutes in the Regulatory State, 103 HARV. L. REV. - (forthcoming 1989).

10. The various writings by Tversky, Kahneman, and others deal principally with heuristics that people use in evaluating probabilities. JUDGMENT UNDER UNCERTAINTY: HEURISTICS AND Brases (D. Kahneman, P. Slovic, A. Tversky eds. 1982). Their goal is to show how rationality breaks down, or is compromised, in different settings; they do not identify the snap decision with the considered judgment, or suggest that the cognitive/noncognitive distinction is incoherent. Indeed, the exact opposite is true: the introduction to the very volume on which Professor Chevigny relies 
An effort to collapse the distinction between the cognitive and noncognitive would also be wildly untrue to huinan experience, in which prejudgments and uninformed intuitions are subject to various forms of testing and reassessment during the process of inaking a decision. ${ }^{11}$ The most obvious exainples here involve means-end rationality of the simplest sort, in which people ask theinselves whether a particular course of action will in fact produce the goals they seek, or whether there are superior alternatives. It would be peculiar to denigrate the role of "logic" here, and snap judgments are often reassessed. Modern social science, inoreover, has provided extremely helpful information on such issues. ${ }^{12}$ The cognitive testing of prejudgments occurs in other contexts as well. Values theinselves einerge partly through a process of deliberation.

All this suggests that the distinction between the cognitive and noncognitive is not incoherent; we can distinguish between forms of expression based on their appeal to different capacities. To say this is not to deny that communication frequently involves noncognitive eleinents, ${ }^{13}$ and it is not to claim that communication is ever purely cogmitive or that the presence of noncognitive elements reinoves speech from first amendment protection. ${ }^{14}$ Indeed, the cognitive/noncognitive distinction should arise only infrequently in first amendinent cases, as in fact it does. ${ }^{15}$ But the question remains whether first amendment doctrime ought to treat some forms of speech—threats, assaults, soine pornography—differently

says that some such heuristics "lead to severe and systematic errors." Id. at 3. A considered judgment necessarily depends on a belief in logic, and that belief underlies most of the modern work in social psychology on heuristics and biases. See also J. Elster, Solomonic JudGMents ch. 1 (1989) (discussing breakdowns in rationality).

I cannot deal with Professor Chevigny's various other sources in this space, but one of the mistakes in his analysis, I think, is to take what is an essentially descriptive work about mental processes-showing various cognitive breakdowns and complexities-as support for the quite different claim that moral or constitutional theory ought not to distingnish between the cognitive and the noncognitive, or that such a distinction is "incoherent." Chevigny, supra note 1 , at 422 .

11. See J. Rawls, A THEORY OF JustiCE 48-51 (1971) (discussing reflective equilibrium, the state reached "after a person has weighed various proposed conceptions and he has either revised his judgments to accord with one of them or held fast to his initial convictions (and the corresponding conception)). Education in general, including legal education, involves precisely these sorts of processes. See M. Nussbaum, The Fragility of Goodness: Luck and ETHics in Greek Tragedy AND Philosophy (1985).

12. Thus, for example, regulation of the environment and of occupational safety and healthnot to mention pornography - should be based on a careful understanding of the likely effects of different enforcement strategies. See, e.g., Rose-Ackerman, Progressive Law and Economics-and the New Administrative Law, 98 Y ALE L.J. 341, 354-60 (1988) (well-informed policy analysis demonstrates that occupational safety and health regulations poorly achieve democratic government's goals of redistribution and aid to working people).

13. See Sunstein, supra note 2 , at 606 \& n.101.

14. Id. at 605-08.

15. See, e.g., United States v. O'Brien, 391 U.S. 367 (1967). 
from others because of the way they communicate their message; and it is to this question to which I now turn.

Second: Those interpreting the first amendment must distinguish between activities that count as "speech" and those that do not. That task is hard enough, but a system of free expression must also distinguish between speech that is and is not central to the purposes of the free speech guarantee. This latter task-to set out categories of "low value" and "high value" expression-is crucial to modern first amendment doctrine; indeed, judge-made doctrine could hardly function without it. ${ }^{16}$

Unless I misread him, Professor Chevigny's approach would make it difficult or impossible to distingnish between activities that count as speech and activities that do not; his approach also would make it hard to distinguish between low- and high-value speech. I am confident that Professor Chevigny would not claim that a long look at a rock formation, a visit to a prostitute, or a summer vacation in Paris, count as constitutionally protected speech-but all of these activities are subject to precisely the same sorts of mental intermediation that Professor Chevigny treats as characteristic to all forms of speech. If so, Professor Chevigny will be forced either to assimilate a quite dazzhing range of activity to the category of constitutionally protected speech-an implausible innovation, I think, on existing doctrine-or to rely on the discredited and untenable distinction between "speech" and "conduct."17

In brief, the first amendment makes it necessary to identify the distinctive characteristics entitling "speech," and not other forms of human experience, to constitutional protection. Any approach that refuses to undertake such a task will be at best incomplete and more likely a muddle. And any approach that does undertake this task will probably conclude that speech is protected at least partly because it involves cognition. In the public realm, cognition-understood to involve deliberative capacities of a wide-ranging sort-provides a central clue to the American commitment to self-government through political processes; and it is here that a central purpose of the first amendinent can be found. ${ }^{18}$ However oversimplified the Enlightenment understanding of

16. See Sunstein, supra note 2 , at 602-05.

17. There might be a third alternative here, but I am unable to think of it.

18. See, e.g., A. MEIKLEJohn, Free SPEech AND ItS Relation to SElf-GovernMENT (1948); J. ELY, DEMOCRACY AND DISTRUST 112 (1980) (must minimize assessment of message's danger if first amendment is to serve its central function of ensuring open political process and dialogue). 
these problems might be, I remam unconvinced that a sensible system of free expression must treat violent pornography in the same way that it treats political speech, or the works of Albert Einstem. ${ }^{19}$

19. Chevigny, supra note 1 , at $423-24$. 